\title{
ВИЗНАЧЕННЯ НАПРЯМІВ ДЕРЖАВНОГО РЕГУЛЮВАННЯ У СФЕРІ ПОЖЕЖНОЇ БЕЗПЕКИ НА ОСНОВІ РОЗГЛЯДУ ДАНИХ СТАТИСТИКИ ПОЖЕЖ
}

О.П. Борис ${ }^{*}$ канд. техн. Наук

Український науково-дослідний інститут цивільного захисту, Україна

\section{ІНФОРМАЦІЯ ПРО СТАТТЮ}

Надійшла до редакції: 31.05.2019

Пройшла рецензування:24.06.2019

КЛЮЧОВІ СЛОВА:

статистика пожеж, загибель

людей, пожежна безпека,

державне регулювання.

\author{
АНОТАЦІЯ \\ Детально проаналізовано статистичні дані щодо виникнення пожеж і \\ загибелі на них людей в Україні за останні десять років, виокремлено \\ негативні аспекти в організації діяльності із забезпечення пожежної \\ безпеки в частині захисту населення від пожеж, обліку пожеж і \\ сформовано відповідні напрями та заходи державного регулювання, \\ спрямовані на підвищення рівня пожежної безпеки в Україні.
}

Постановка проблеми. Сфера пожежної безпеки $\epsilon$ складовою частиною безпеки життєдіяльності, що спрямована на захист здоров'я та життя людини. Особливе місце серед можливих загроз безпеки населення належить пожежам. Тенденція до збільшення їх кількості впродовж останніх десятих років в Україні залишається чітко вираженою. Водночас, розподіл пожеж між міською територію та сільською місцевістю складає в середньому різницю у $60 \%$ та $40 \%$, а кількість загиблих на пожежах у містах і селах мають діаметрально протилежні значення. Загалом стан із загибеллю людей на пожежах в Україні, хоч і має упродовж останніх років тенденцію до зниження, залишається складним. Україна посідає четверте місце за кількістю загиблих на 100 тис. населення серед країн світу, а в цілому за визначеним статистичним критерієм національний показник значно перевищує загальносвітове середньостатистичне значення.

Дані світової статистики пожеж свідчать про наявний дисонанс між кількістю пожеж і загиблих на них людей в Україні та $€$ підставою для удосконалення державного управління у сфері пожежної безпеки, в першу чергу пов'язаного із захистом населення від пожеж. На зазначені обставини прямо чи опосередковано впливають процеси й явища в економічній, соціальній сферах життя суспільства, що мають тенденцію до ускладнення. Водночас, основні негативні аспекти проблематики полягають у недоліках організації діяльності існуючого в державі механізму реагування на пожежі в частині своєчасного прибуття пожежно-рятувальних підрозділів до місць виклику. Такі обставини потребують формування та запровадження відповідних заходів державного регулювання, спрямованих на підвищення рівня пожежної безпеки в Україні.

Формулювання цілей досліджень. Метою даної статті $є$ проведення огляду статистичних даних про пожежі в Україні за 2009-2018 роки та формування на його підставі напрямів державного регулювання у сфері пожежної безпеки.

\section{Виклад основного матеріалу} дослідження. Кількість пожеж в Україні впродовж останніх років поступово збільшується, a їх поділ між міською територією та сільською місцевістю залишається фактично незмінним і складає щорічно у відносних значеннях $60 \%$ та $40 \%$ (рис. 1) [1]

Зростання кількості пожеж в Україні не слід вважати негативною тенденцією. У порівнянні із даними стосовно динаміки кількості пожеж у країнах світу за 2012-2016 роки, виникає питання щодо відповідності їх обліку в Україні $[2,3]$. Так, кількість пожеж на 1 тис. чол. в рік, у відносно наближених за чисельністю населення країнах $\mathrm{EC}$, складає показник 2,83 та 3,98 (Іспанія - 47079 тис. чол. та Польща - 38454 тис. чол.) проти 1,67 в Україні (42 673 тис. чол.), що в середньорічних значеннях відповідає 133066 та 153125 пожежам проти 71 065. Таким чином, можна впевнено стверджувати про недосконалість обліку пожеж в Україні, що на практиці пов'язана із неможливістю класифікації як пожеж коротких замкнень електромереж (приладів) і горіння на відкритих територіях.

На проблему забезпечення безпеки населення вказують також інші показники, зокрема кількість загиблих на пожежах. На рис. 2 наведено кількість загиблих людей у розрахунку на 100 тис. чол. у деяких країнах світу та в Україні у 2016 році [2].

*E-mail: boris@undicz.dsns.gov.ua 


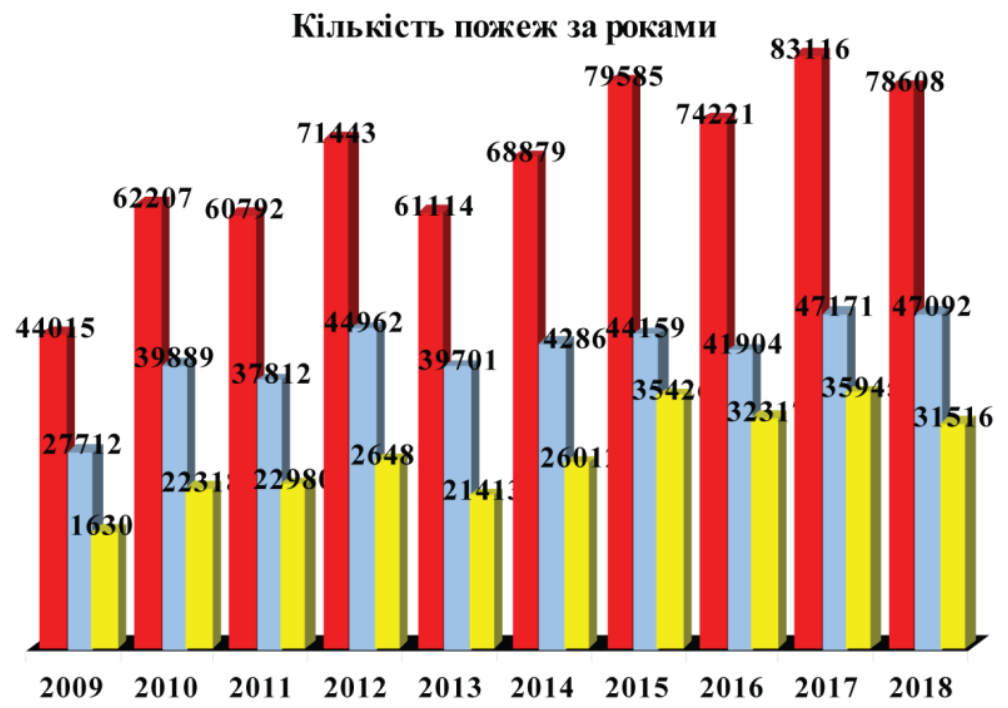

\footnotetext{
—ількість пожеж всього Кількість пожежу містах і смт Шількість пожеж у сільскій місцевості з 2014 року без урахування АР Крим і м. Севастополь
}

Рисунок 1 - Кількість пожеж в Україні за 2009-2018 роки та їх поділ між міською територією та сільською місцевістю

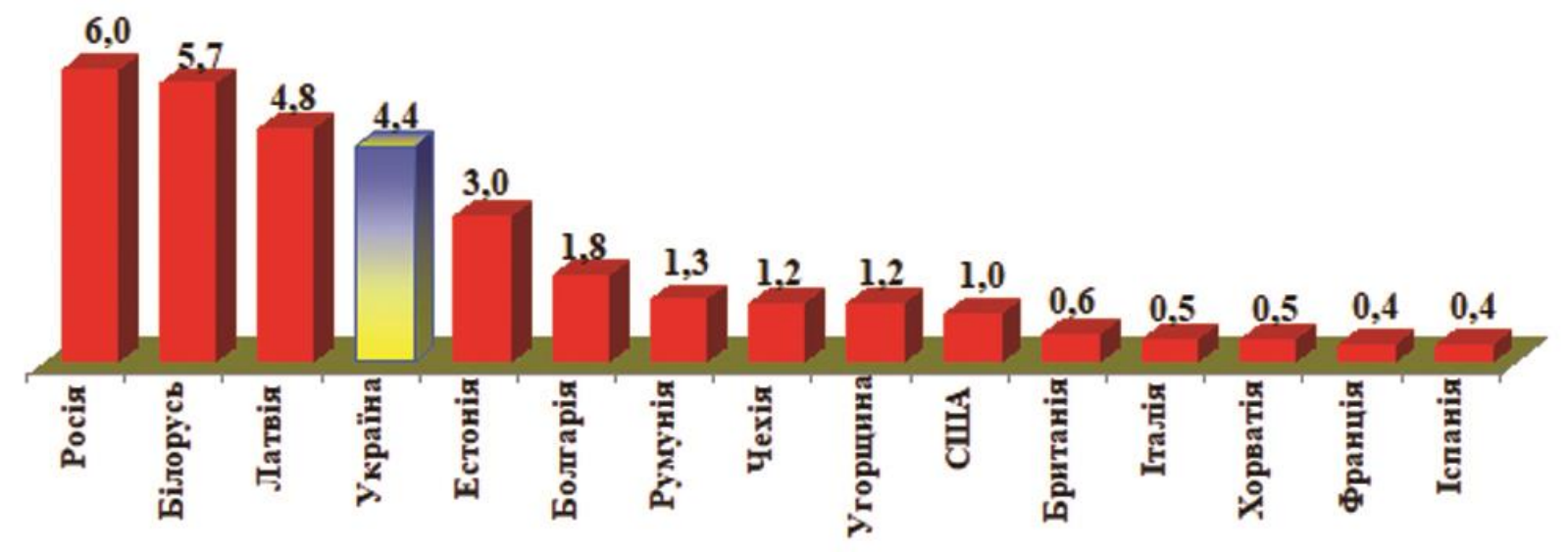

Рисунок 2 - Кількість загиблих людей у розрахунку на 100 тис. чол. у деяких країнах світу у 2016 році

В Україні, у порівнянні із минулим оглядом пожеж [4], зазначений показник дещо покращений, але в цілому стан із загибеллю людей на пожежах залишається вкрай незадовільним. Для порівняння, у 2016 році в Україні показник кількості загиблих на 100 пожеж склав 2,5 проти середнього значення для країн $€ \mathrm{C}-0,5$, що у чистих значеннях складає 1872 проти 2184 [2].

Слід зазначити, що в Україні упродовж останніх десяти років за умов постійного скорочення населення (більше, ніж на 3,6 млн), спостерігається загальна тенденція щодо зменшення кількості загиблих унаслідок пожеж. (рис. 3) [5].
Разом із тим, відносні показники кількості загиблих людей на 100 тис. чол. населення залишаються високими (рис. 4).

Особливе занепокоєння викликає розподіл кількості загиблих на пожежах на 100 тис. чол. населення між міською територію та сільською місцевістю. В містах України унаслідок пожеж у 2018 році загинуло 886 людей, що складає 45,3\% від загальної кількості загиблих, а у сільській місцевості - 1070 людей, що становить 54,7\%. Водночас, чисельність населення у містах i селищах міського типу майже вдвічі більша за чисельність сільського населення. Зазначене співвідношення та динаміка кількості загиблих за 2009-2018 роки наведені на рис. 5. 


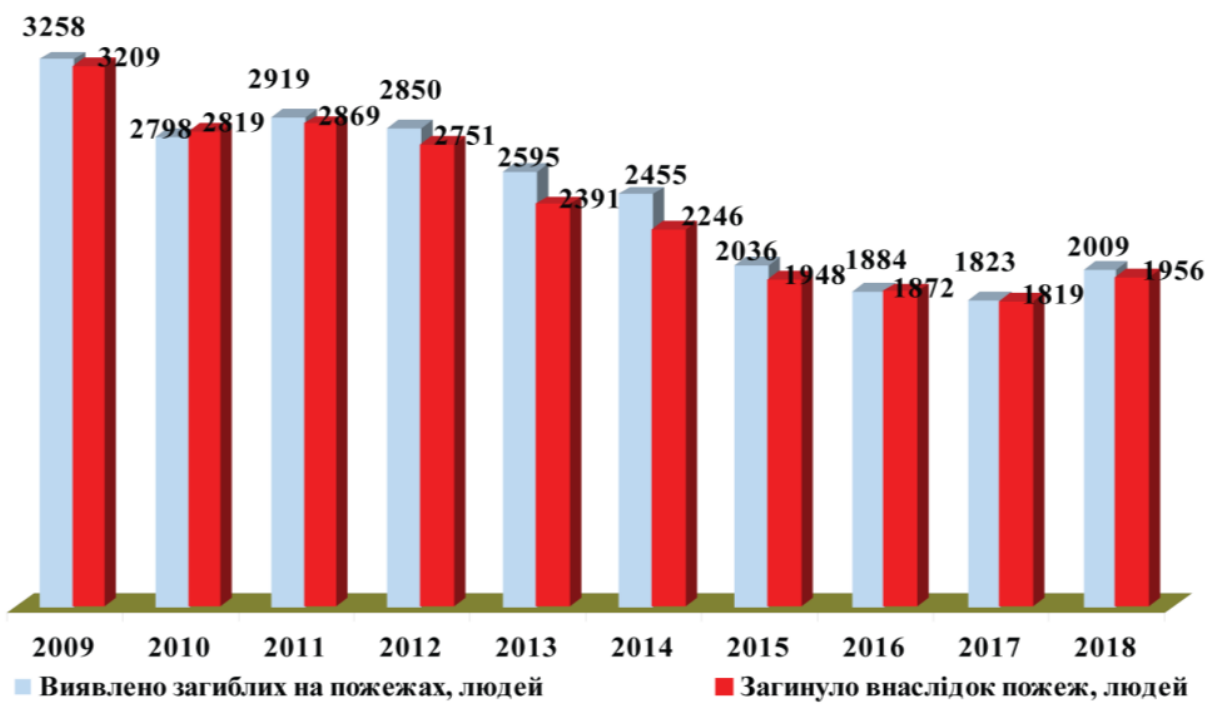

Рисунок 3 - Розподіл кількості загиблих, виявлених на пожежах,

та кількості загиблих унаслідок пожеж людей за 2009-2018 роки

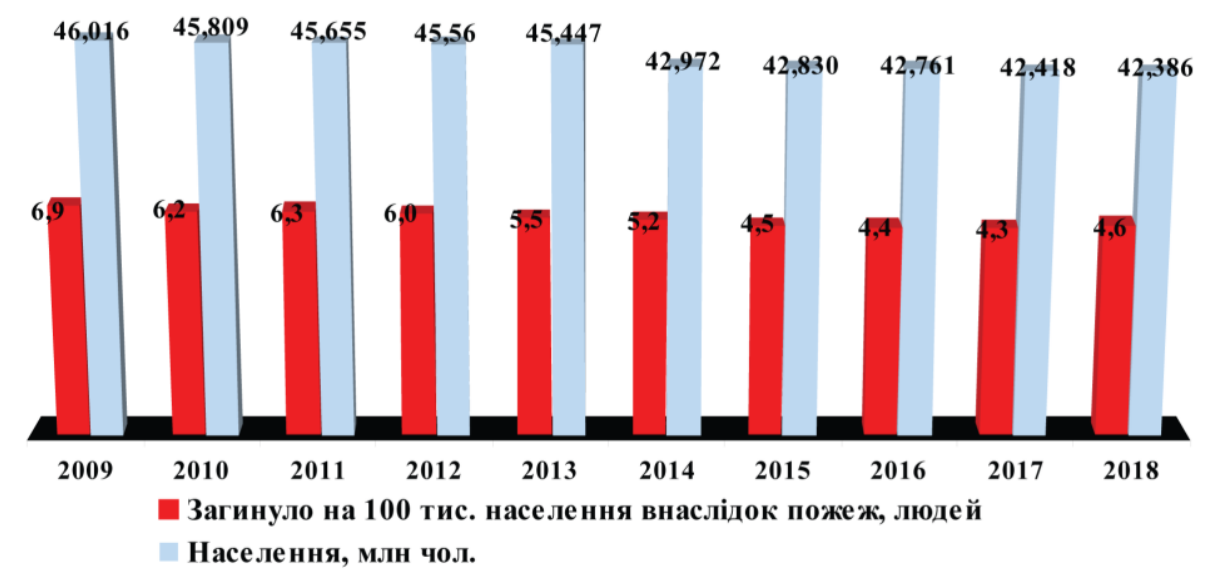

Рисунок 4 - Динаміка кількості населення в Україні та кількості загиблих людей унаслідок пожеж в Україні у розрахунку на 100 тис. чол. за 2009-2018 роки

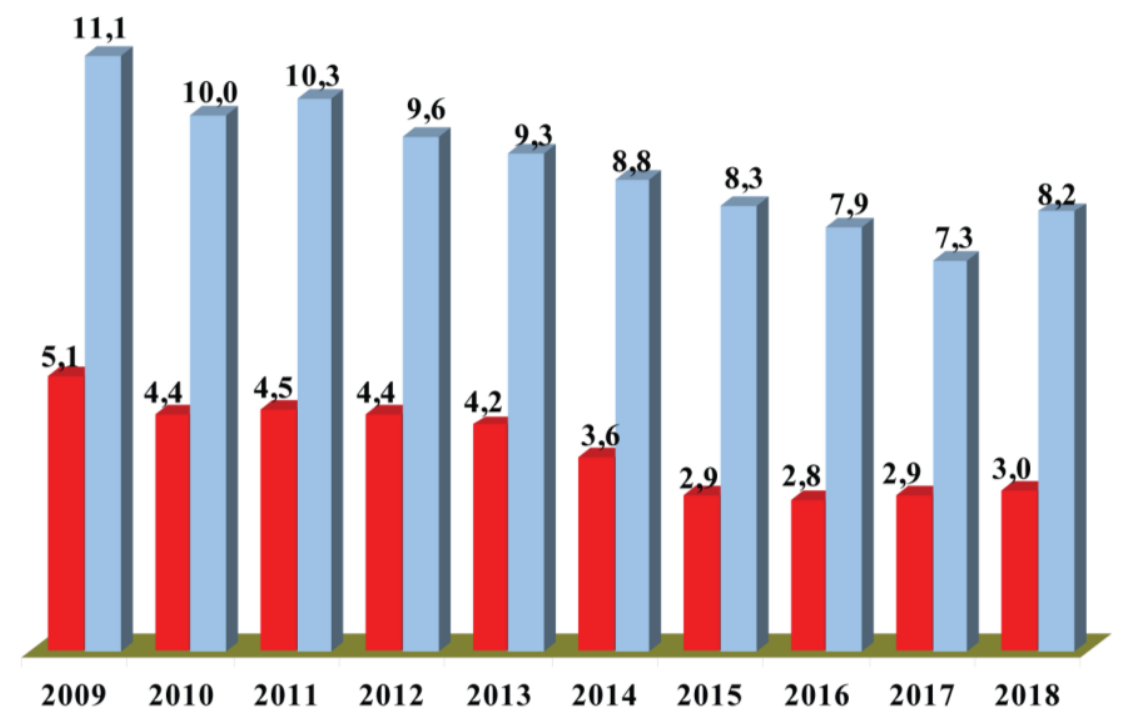

— Кількість загиблих унаслідок пожеж у містах і смт на 100 тис. населення

шількість загиблих унаслідок пожеж у сільській місцевості на 100 тис. населення

Рисунок 5 - Динаміка кількості загиблих унаслідок пожеж на 100 тис. населення у містах і сільській місцевості за 2009-2018 роки 
Загибель унаслідок пожеж у сільській місцевості в середньому у 2,6 рази вища, ніж на міській території. У містах показник загиблих на 100 тис. чол. в середньому складає 3,8 , а в селах - 9,0, що, в першу чергу, обумовлене кількістю пожежно-рятувальних підрозділів і пожежної техніки, які зосереджені на адміністративних територіях.

Дані світової статистики показують, що серед країн ЄС площа обслуговування одним пожежним депо в Україні $\epsilon$ найбільшою $\mathrm{i}$ становить 624 км² (для прикладу: у Франції - 99

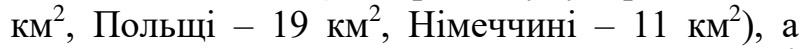
кількість пожежної техніки на площу в 1 тис. км ${ }^{2}$ - однією з найменших і становить 6 одиниць (у Франції - 13 од., Польщі - 65 од., Німеччині 122 од.) [6].

Аналіз загибелі людей унаслідок пожеж за часом прибуття пожежно-рятувального підрозділу та умов, що вплинули на поширення пожеж, свідчить, що у 2018 році 28,9\% людей у містах та $42,2 \%$ людей у сільській місцевості загинули внаслідок пожеж, час прибуття на які перевищував норматив часу прибуття пожежнорятувальних підрозділів до місця виклику, а саме до 10 хвилин у містах і селищах міського типу та до 20 хвилин у сільських населених пунктах $[7,8,9]$, що, здебільшого, обумовлено віддаленістю пожежних депо.

Зважаючи на вищезазначене, можна виділити основні напрями державного регулювання, спрямованні на вдосконалення сфери пожежної безпеки, що стосуються відповідності існуючого обліку пожеж їx реальній кількості та вдосконалення системи реагування на пожежі в сільський місцевості.

Результати опрацювання нормативноправових актів та інших документів, що регламентують здійснення обліку пожеж та їх наслідків у країнах-членах Свропейського Союзу та інших країнах світу $[10,11]$, свідчать про те, що підхід до обліку загиблих i травмованих на пожежах практично однотипний. Однак, в Україні термічне розкладання (горіння) електроприладів i загоряння на відкритих територіях поза межами населених пунктів, що не завдали збитків, не класифікуються як пожежі. Таким чином, заходом державного регулювання, спрямованим на удосконалення обліку пожеж в Україні, слід визначити внесення змін до [3] та вилучення абзаців 4 та 5 ст. 6 «Не підлягають обліку», а саме: «випадки коротких замикань» та «випадки горіння відходів та сміття на відкритій території».

Удосконалення системи реагування на пожежі має полягати в усуненні існуючих нерівноцінних норм $[7,8,9]$ щодо прибуття пожежно-рятувальних підрозділів до місця виклику та встановленні єдиного нормативу прибуття для міст і сільських населених пунктів.

Висновки. Захист населення України від пожеж потребує значного покращення. Відносні показники кількості загиблих людей на 100 тис. чол. населення в Україні залишаються високими і значно перевищують показник провідних країн світу. Безпосередньо в Україні значною проблемою $\epsilon$ забезпечення захисту населення від пожеж у сільський місцевості, де чисельність населення вдвічі більша ніж у містах і селищах міського типу, проте кількість людей, загиблих унаслідок пожеж на 100 тис. чол. в середньому у 2,6 рази вища. Водночас, близько $30 \%$ людей у містах та $40 \%$ людей у селах гинуть на пожежах, час прибуття на які пожежнорятувальних підрозділів перевищує нормований.

Таким чином, на підставі вищезазначеного можна зробити висновок щодо необхідності вдосконалення державного управління в сфері пожежної безпеки. Основними напрямами державного регулювання слід визначити вдосконалення системи обліку пожеж та унормування часу прибуття пожежнорятувальних підрозділів до місця виклику. Водночас, заходи державного регулювання сфери пожежної безпеки полягають у внесені змін до існуючих нормативно-правових актів України $[3,7,8,9]$.

Також слід зазначити, що для визначення та формування більш детальних заходів державного регулювання у сфері реагування на пожежі необхідно провести грунтовний аналіз існуючої системи державного управління у сфері цивільного захисту та пожежної безпеки, a саме: провести комплексну оцінку ефективності існуючих практик реагування на небезпечні події, вивчити правові основи та нормативні критерії роботи пожежнорятувальних підрозділів країн-членів ЄС. 


\section{СПИСОК ЛІТЕРАТУРИ}

1. Климась Р.В. Аналіз статистичних даних щодо реагування на небезпечні події, пов'язані з пожежами, в Україні / Р.В. Климась, Д.Я. Матвійчук, А.В. Одинець, Л.П. Несенюк // Запобігання надзвичайним ситуаціям i їх ліквідація. Матеріали науково-практичного семінару. - Харків: НУЦЗУ, 2019. - С. 76-78.

2. Brushlinsky N.N., Ahrens Marty, Sokolov S.V., Wagner Peter. World Fire Statistics. Report № 22. - International Assosiation of Fire and Rescue Services (CTIF): Copyright by Center of Fire Statistics of CTIF, 2017. $-56 \mathrm{p}$.

3. Постанова Кабінету Міністрів України від 26 грудня 2003 року № 2030 «Про затвердження Порядку обліку пожеж та їх наслідків» (Офіційний вісник України, 2003 р., № 52, ст. 2802).

4. Oleksandr Borys Review of Fire Statistics Data in Ukraine. Bezpieczeństvo I Technika Pożarnicza Safety \& Fire Techique. BiTP Vol. 47 Issue 3, 2017, pp. 62-67, doi: 10.12845/bitp.47.3.2017.4.

5. Звіт про науково-дослідну роботу «Провести дослідження тенденцій і закономірностей динаміки основних показників статистики пожеж в Україні за територіальним принципом». - К.: УкрНДІЦЗ, 2018. - 756 с.

6. Климась Р.В. Аналіз нормативу часу прибуття першого пожежно-рятувального підрозділу на пожежі в Україні / Р.В. Климась, А.В. Одинець, Д.Я. Матвійчук, Л.П. Несенюк // Теорія і практика гасіння пожеж та ліквідації надзвичайних ситуацій: Матеріали $\mathrm{X}$ Міжнародної науково-практичної конференції. Черкаси: ЧІПБ ім. Героїв Чорнобиля НУЦЗ України, 2019. - С. 32-34.

\section{REFERENCES}

1. Klymas R.V., Matviichuk D.Ia., Odynets A.V., Neseniuk L.P. (2019) Analiz statystychnykh danykh shchodo reahuvannia na nebezpechni podii, poviazani $\mathrm{z}$ pozhezhamy, $\mathrm{v}$ Ukraini Analysis of statistical data on response to hazardous events associated with fires in Ukraine]. Proceedings of the «Zapobihannia nadzvychainym sytuatsiiam i yikh likvidatsiia. Materialy naukovo-praktychnoho seminaru», Kharkiv, NUCZU, pp. 76-78. (in Ukrainian)

2. Brushlinsky N.N., Ahrens Marty, Sokolov S.V., Wagner Peter. World Fire Statistics. Report № 22. - International Assosiation of Fire and Rescue Services (CTIF): Copyright by Center of Fire Statistics of CTIF, 2017. $-56 \mathrm{p}$.

3. Postanova Kabinetu Ministriv Ukrainy vid 26 hrudnia 2003 roku № 2030 «Pro zatverdzhennia Poriadku obliku pozhezh ta yikh naslidkiv» (Ofitsiinyi visnyk Ukrainy, 2003 r., № 52, st. 2802).

4. Oleksandr Borys Review of Fire Statistics Data in Ukraine. Bezpieczeństvo I Technika Pożarnicza Safety \& Fire Techique. BiTP Vol. 47 Issue 3, 2017, pp. 62-67, doi: 10.12845/bitp.47.3.2017.4.

5. Provesty doslidzhennia tendentsii i zakonomirnostei dynamiky osnovnykh pokaznykiv statystyky pozhezh $\mathrm{v}$ Ukraini za terytorialnym pryntsypom [Conduct research of trends and regularities of dynamics of the main indicators of fire statistics in Ukraine by territorial principle]. Zvit pro NDR, K.: UkrNDICZ, 2018, 756 p.
7. Постанова Кабінету Міністрів України від 27 листопада 2013 року № 874 «Про затвердження критеріїв утворення державних пожежно-рятувальних підрозділів (частин) Оперативно-рятувальної служби цивільного захисту в адміністративно-територіальних одиницях та переліку суб'єктів господарювання, де утворюються такі підрозділи (частини)» (Офіційний вісник України, 2013 р., № 96, ст. 3555).

8. Розпорядження Кабінету Міністрів України від 25 січня 2017 року № 61-р «Про схвалення Стратегії реформування системи Державної служби України з надзвичайних ситуацій» (Офіційний вісник України, 2017 р., № 13, ст. 373).

9. Державні будівельні норми ДБН Б.2.2-12:2018 Планування і забудова територій. - К.: Мінрегіон України, 2018. - 179 с.

10. Климась Р.В. Шляхи удосконалення статистичного обліку пожеж та їх наслідків в Україні на регіональному та державному рівнях / Р.В. Климась, Д.Я. Матвійчук // Науковий вісник УкрНДІПБ. - К.: 2011. - № 2(24). - С. 54-58.

11. Звіт про науково-дослідну роботу «Провести дослідження та науково обгрунтувати шляхи удосконалення обліку пожеж та їх наслідків в Україні». - К.: УкрНДІЦЗ, 2017. - 1049 с.

6. Klymas R.V., Matviichuk D.Ia., Odynets A.V., Neseniuk L.P. (2019) Analiz normatyvu chasu prybuttia pershoho pozhezhno-riatuvalnoho pidrozdilu na pozhezhi v Ukraini [Analysis of the standard arrival time of the first fire and rescue unit to a fire in Ukraine]. Proceedings of the «Teoriia i praktyka hasinnia pozhezh ta likvidatsii nadzvychainykh sytuatsii: Materialy X Mizhnarodnoi naukovo-praktychnoi konferentsii», Cherkasy: ChIPB im. Heroiv Chornobylia NUCZU, pp. 32-34. (in Ukrainian)

7. Postanova Kabinetu Ministriv Ukrainy vid 27 lystopada 2013 roku № 874 «Pro zatverdzhennia kryteriiv utvorennia derzhavnykh pozhezhno-riatuvalnykh pidrozdiliv (chastyn) Operatyvno-riatuvalnoi sluzhby tsyvilnoho zakhystu v administratyvno-terytorialnykh odynytsiakh ta pereliku subiektiv hospodariuvannia, de utvoriuiutsia taki pidrozdily (chastyny)» (Ofitsiinyi visnyk Ukrainy, 2013 r., № 96, st. 3555).

8. Rozporiadzhennia Kabinetu Ministriv Ukrainy vid 25 sichnia 2017 roku № 61-r «Pro skhvalennia Stratehii reformuvannia systemy Derzhavnoi sluzhby Ukrainy $\mathrm{z}$ nadzvychainykh sytuatsii» (Ofitsiinyi visnyk Ukrainy, 2017 r., № 13, st. 373).

9. Derzhavni budivelni normy DBN B.2.2-12:2018 Planuvannia i zabudova terytorii. - K.: Minrehion Ukrainy, 2018. - $179 \mathrm{~s}$. 
10. Klymas R.V., Matviichuk D.Ia. (2011) Shliakhy udoskonalennia statystychnoho obliku pozhezh ta yikh naslidkiv $\mathrm{v}$ Ukraini na rehionalnomu ta derzhavnomu rivniakh [Ways to improve the statistical accounting of fires and their consequences in Ukraine at the regional and state levels.]. Naukovyi visnyk UkrNDIPB, K., vol 2(24), pp. 54-58. (in Ukrainian)

11. Provesty doslidzhennia ta naukovo obgruntuvaty shliakhy udoskonalennia obliku pozhezh ta yikh naslidkiv v Ukraini
[Conduct research and scientifically substantiate ways to improve the accounting of fires and their consequences in Ukraine]. Zvit pro NDR, K.: UkrNDICZ, 2017, 1049 p. 


\section{DETERMINATION OF PUBLIC REGULATION DIRECTIONS IN THE SPHERE OF FIRE SAFETY ON THE BASIS OF CONSIDERATION OF DATA OF FIRE STATISTICS}

O. Borys, Cand. of Sc. (Eng.)

The Ukrainian Civil Protection Research Institute, Ukraine

\section{KEYWORDS}

fire statistics, death of people, fire safety, public regulation.

\begin{abstract}
ANNOTATION
A review of statistics on the occurrence of fires and the death of people in Ukraine in the last ten years has been carried out. The studies were conducted using methods of mass statistical monitoring, statistical generalization and grouping, statistical processing of generalized indices as well as those divided into groups, and thorough qualitative analysis of the statistical data. In comparison with the world fire statistics, in Ukraine the unsatisfactory state in the sphere of fire safety remains, primarily associated with the protection of the population from fires. The facts of the imperfect organization of the state response system to fires were established, the need for further scientific analysis of fire statistics and the study of existing mechanisms and practices for registering fires and responding to dangerous events (fires) in the EU countries, the introduction of a national system of evaluating the effectiveness of fire and rescue units in Ukraine, development of measures of public administration in the sphere of fire safety, aimed at increasing the level of protection of the population from fires. In order to formulate directions and measures of public administration regarding the protection of the population from fires in Ukraine, it is necessary to conduct a thorough scientific analysis of the existing public administration system in the sphere of civil protection and fire safety, namely: to carry out research of existing practices on the statistical accounting of fires; carry out a comprehensive assessment of the effectiveness of existing mechanisms and practices for responding to dangerous events; to study legal bases and normative criteria of work of fire and rescue units of Ukraine in comparison with EU member states.
\end{abstract}

\section{ОПРЕДЕЛЕНИЕ НАПРАВЛЕНИЙ ГОСУДАРСТВЕННОГО РЕГУЛИРОВАНИЯ В СФЕРЕ ПОЖАРНОЙ БЕЗОПАСНОСТИ НА ОСНОВЕ РАССМОТРЕНИЯ ДАННЫХ СТАТИСТИКИ ПОЖАРОВ}

А. П. Борис, канд. техн. наук Украинский научно-исследовательский институт гражданской защиты, Украина

\section{КЛЮЧЕВЫЕ СЛОВА}

статистика пожаров, гибель людей, пожарная безопасность, государственное регулирование.

\begin{abstract}
АННОТАЦИЯ

Детально проанализированы статистические данные о
возникновении пожаров и гибели на них людей в Украине за последние десять лет, выделены негативные аспекты в организации деятельности по обеспечению пожарной безопасности в части защиты населения от пожаров, учета пожаров и сформированы соответствующие направления $и$ меры государственного регулирования, направленные на повышение уровня пожарной безопасности в Украине.
\end{abstract}

